\title{
Improving Students' Problem Solving Ability Through Learning Based Videoscribe
}

\author{
Yoga Budi Bhakti ${ }^{1}$, Irnin Agustina Dwi Astuti ${ }^{2}$, Eva Yuni Rahmawati ${ }^{3}$ \\ Faculty of Mathematic and Science, Universitas Indraprasta PGRI, Indonesia ${ }^{1,2,3}$ \\ bhaktiyoga.budi@gmail.com¹, irnin.agustina@gmail.com², everez29@gmail.com
}

Received: January $8^{\text {th }}, 2020$. Revised: May $17^{\text {th }}, 2020$. Accepted: May $19^{\text {th }}, 2020$

\author{
Keywords : \\ Problem Solving Ability; \\ Learning Media; Videoscribe; \\ Physics Learning
}

\begin{abstract}
The purpose of this research is to find out the problemsolving physics by using media-based videoscribe learning. Learning with the help of a video will make students more interactive and active because students can understand the concept of abstract and solve the problem of physics related to daily life. The method used in this research was the quasiexperimental method with the research design of The Randomized Post-Test Only Control Group Design, which involved 30 students as samples in Physics Education of Indraprasta PGRI University.The technique analysis of the research using the T-test. The results showed that by using learning media videoscribe could improve the ability of problem-solving physics. We found significant positive effects of the use of videoscribe in conveying physics lessons With the help of video scribe, learning is more efficient in physics learning. The students understand abstract physics material and are able to activate students in learning. These findings are consistent with studies on the improve of the student's problem-sloving ability on physics learning.
\end{abstract}

\section{INTRODUCTION}

Undergraduate students are required to have academic skills (hard skills) and soft skill. These skills are very useful after they graduated from university and ready to work [1]. It means that they are not only master the theory but also have the ability. Program study of natural science should provide sufficient theories and provide the real projects, so the students learn how to solve the problem through their learning strategies. Students must learn all domains, namely cognitive, affective, and psychomotor. It is very different while someone is studying at the university and at school. At the university level, the physics learning is more emphasized to the real concept and application of the physics material, not only understanding theory [2]. Practice activities aimed to improving the skills of students need to be done to deepen the physics material. The physics materials learned should be analyzed more complex so that students are accustomed to the high thinking abilities that can improve the ability of problem solving physics.

The electrical measuring instrument course at the university level, students learn to make and use various kinds of electrical measuring devices such as ammeters, voltmeters, potentiometers, and oscilloscopes. 
In addition, the students learn to apply electrical measuring devices in daily life. In fact, based on the results interview in Indraprasta PGRI University, there are a lot of students didn't like the concept of electricity or electronics because it was too complicated either in making the series or in studying the analysis. It causes the students to lack of motivation in learning. The effect of the students who were taught the only concept of electricity, they faced difficulty to solve the problem in electricity. It can be seen that the students' problem-solving ability is still low. This lack of understanding often occurs because students are unable to visualize the distribution of forces throughout a vector field. In short, research suggests, that students lack a qualitative under- standing of the highlighted electric field concepts [3]. It is believed that building such qualitative mental models lays the foundation for students' development of a more scientific, abstract understanding of electric field models.

Problem-solving is an aspect of applying concepts of physics that can be gained through the learning process. The need for problem solving arise when someone wants to achieve the goal. Generally physics exercises are the task that needs a process from the initial condition to the desired final condition. The action steps that are well-identified will produce solutions or problem solving [4-5]. The students' problem-solving ability is influenced by cognitive abilities/ mental activity (brain) in understanding the context of the exercises given [6]. The more understanding concepts and principles of physics, the better skills in solving physics problems. While facing physics problems, the students need to build a relation between prior knowledge and new knowledge, in order to find a solution [7]. The solution to overcome the problem solving that faced by the students, is a challenge for the lecturers. The lecturers must be creative in applying new methods to improve learning that has not been maximized. The method must be effective, which is adapted to the students' needs, so they can learn well. Giving more opportunities in problem-solving will make students more experienced in solving physics problems [8].

In teaching and learning process, there are two important elements, namely teaching methods and learning media. Both aspects are interrelated. Selection one of the teaching method will affect the type of learning media which is appropriate. Creating learning media must be adapted to the students' need and the compatibility of the material taught. Multimedia learning theories mainly focus on the cognitive processing involved in learning Fundamental principle behind multimedia learning is that people learn better fromwords and pictures than from words alone [9]. Using both words, including written and spoken text, and pictures, including static images and video, lets the brain process more information in working memory . In recent years, several researchers emphasized the possible role of motivation in multimedia learning. Moreno and Mayer highlight that emotional and motivational factors mediate learning by affecting cognitive engagement, he proposed the cognitive affective theory of learning with media (CATLM) to better incorporate the role of motivational and metacognitive factors in multimedia learning and to extend cognitive theory of multimedia learning [10-11].

Computer application based video learning is often used in learning are by operating software photoshop story, scratch, sparkol videoscribe, and powtoon. These software/ application are used to support learning process and to enhance students' knowledge and skills [12]. The learning sciences is an interdisciplinary field, and a video is a tool that enhances various methodologies associated with different, and some would argue incommensurate, philosophical orientations [13].

One of the video learning which is used in this research is video learning based videoscribe. Audio visual media using videoscrive to present some information and increase the effectiveness in learning process [14]. Videoscribe enables one to illustrate the complicated material concept, improve the students' interest and students' motivation [15]. Videoscribe is a software used by teachers and students to create animated whiteboards to increase interest and retention in learning. Videoscribe has advantages because videoscribe is an online application with multimedia nuances and can be in the form of photos, images, text, music, and backgrounds that can be chosen as desired [14]. With a variety of characters contained in videos, generally it can improve the learning process more alive and not monotonous, because learning is more varied. Videoscribe can improve learning by combining audio and visual. According to Rahmawati \& Kardi, students better understand the concepts of learning with animation [16]. Using technological tools in learning can improve understanding of student's scientific concepts. 
Technology can transform an abstract material into a more tangible, so that students can understand the material well. Technology is also able to increase the interest and activity of student learning [17-18].

\section{METHOD}

The method used in this research was the quasi-experimental method with the research design of The Randomized Post-Test Only Control Group Design, which involved 30 students as samples in Physics Education of Indraprasta PGRI University. Sample determination used random sampling cluster technique. The learning instruments were a lesson plan, video learning and problem-solving ability test. The variable was measured by using a problem-solving ability test. This research used three data collection method, namely (1) documentation method, (2) the questionnaire method and (3) test method. Documentation is a method of collecting data by collecting a lot of documents and recording systematically. The document recording is done by making a report about the stages that have been done in developing a learning video. The questionnaire method used to know of the students respone of physics learning. The test method to know of problem-solving ability of the students.

Table 1. The indicator of problem-solving ability instrument

\begin{tabular}{|c|c|c|}
\hline Stage & Indicator & No. Question \\
\hline \multirow[t]{3}{*}{ Visualize the problem } & $\begin{array}{l}\text { Visualizing problems into } \\
\text { visual representations }\end{array}$ & 1,2 \\
\hline & $\begin{array}{l}\text { Identifying issues based on } \\
\text { basic concepts }\end{array}$ & 3,4 \\
\hline & Determine the asked size & 5 \\
\hline \multirow[t]{2}{*}{$\begin{array}{l}\text { Describe the problem in physics } \\
\text { description }\end{array}$} & $\begin{array}{l}\text { Converting visual } \\
\text { representation into a physic } \\
\text { description }\end{array}$ & 6 \\
\hline & $\begin{array}{l}\text { Create a free object } \\
\text { diagram/sketch describing the } \\
\text { problem }\end{array}$ & 7,8 \\
\hline \multirow[t]{2}{*}{ Plan the solution } & $\begin{array}{l}\text { Transforming a physics } \\
\text { description into a mathematical } \\
\text { representation }\end{array}$ & 9,10 \\
\hline & $\begin{array}{l}\text { Determining the right equation } \\
\text { for troubleshooting }\end{array}$ & 11 \\
\hline \multirow[t]{2}{*}{ Execute the plan } & $\begin{array}{l}\text { Substituted the known } \\
\text { magnitude value to the equation }\end{array}$ & 12 \\
\hline & $\begin{array}{l}\text { Perform calculations using the } \\
\text { selected equation }\end{array}$ & 13 \\
\hline Check and evaluate & $\begin{array}{l}\text { Evaluating compliance with the } \\
\text { concept }\end{array}$ & 14,15 \\
\hline
\end{tabular}

The improvement of students problem solving ability can be seen from the data pretest and posttest, analysis before and after using video learning used paired t-test or test dependent or paired sample t-test which is used to compare the average of two data set (data before and after) in pairs. This paired t-test carriec out using IBM SPSS Statistics 20.0.

\section{RESULTS AND DISCUSSIONS}

Before learning in class, teachers give pretests to know the ability of problem solving students. The results were $40 \%$ of student submission, the averagre is 52 , the maximal value is 74 , and the minimal value is 40 . This indicates the ability of problem solving students are still low. Students are also still 
confused to argue and overcome the physical problems associated with daily life. Physics learning is preliminary with the introduction and the Apertion, then the teacher conveys the learning objectives. The material is conveyed by providing video learning based Videoscribe which is uploaded on YouTube. Students can study electrical material. After students learn the material, then the teacher conducts a discussion with the students. At the time of student discussions are very enthusiastic and active in class. Students ' ability to improve. Students who are essentially afraid to speak to dare to communicate. After that the teacher provides evaluation (postest) to know the ability of problem solving students. The value of pretest and postest is visible on table 2 .

Table 2. The value of pretest and postest

\begin{tabular}{lcc}
\hline & $\begin{array}{c}\text { Before using the } \\
\text { videoscribe }\end{array}$ & $\begin{array}{c}\text { After using the } \\
\text { videoscribe }\end{array}$ \\
\hline Average & 52 & 81 \\
Maximal value & 74 & 94 \\
Minimal value & 40 & 72 \\
Learning submission $(\%)$ & $40 \%$ & $89 \%$ \\
\hline
\end{tabular}

Before conducting data analysis with t-test paired, the data must be tested in order to know whether the data is spread normally or not.. the test statistic used is Lilliefors (Kolmogorov-Smirnov) normality test. Because of p-value normality test for the data before and after giving medicine is more than 0.05 , the the statistical conclusion means that $\mathrm{H} 0$ is accepted, it can be said that both data come from populations that are spread normally. In other words, the data is normally distributed (with p-value $=0.713$ ). therefore, paired t-tests can be applied. Data analysis with SPSS 20 in paired t-test can explained in the following table.

Table 3. The results of paired t-test with SPSS

\begin{tabular}{|c|c|c|c|c|c|c|c|c|}
\hline & \multicolumn{5}{|c|}{ Paired Differences } & \multirow{3}{*}{$\mathbf{t}$} & \multirow{3}{*}{ df } & \multirow{3}{*}{$\begin{array}{l}\text { Sig }(2- \\
\text { tailed) }\end{array}$} \\
\hline & \multirow[t]{2}{*}{ mean } & \multirow[t]{2}{*}{ Std dev } & \multirow[t]{2}{*}{$\begin{array}{c}\text { Std } \\
\text { error }\end{array}$} & \multicolumn{2}{|c|}{$\begin{array}{l}95 \% \text { confidence } \\
\text { interval of the } \\
\text { difference }\end{array}$} & & & \\
\hline & & & & Lower & Upper & & & \\
\hline $\begin{array}{l}\text { Pair1 } \\
\text { Pretest- } \\
\text { posttest }\end{array}$ & 29,33 & 10,258 & 1,873 & 33,183 & 25,504 & 15,585 & 29 & 0,000 \\
\hline
\end{tabular}

$\mathrm{P}$-value from paired t-test as shown in table 4 is 0.000 , which is smaller than 0.05 . thus, the statistical conclusion is to reject $\mathrm{H} 0$. It means that the problem solving ability of electric measuring devices before and after giving an action is not equal to zero. It means that there are significant differences on students' problem solving abilities between before and after using video learning. The difference score average between pretest and posttest is 29.33 . Thus, it can be concluded that thea pplication of videoscribe based learning video is effectively used in learning electrical measuring devices with a trusted level of 95\%.Based on the mean posttest score which is more than the mean pretest, it can be concluded that the learning video can improve students' problem solving ability in electrical measuring courses. It is appropriate with the theory stated by Kustiani in Erniwati [19], the students can learn more easily by using video, eaither at school or aat home. The children are easier to learn about things that are concrete than abstract ones. Learning physich which is abstract will be more easily to learn when it stars from something concrete or real [20]. In line with Yusuf [21] research by applying audio visual media using videoscribe as a tool to give the information, it also can increase students' motivation and curiosity in learning and understanding the material, because the way delivering the material is interesting and easy to understand. Students easily get the material, and video learning materials can also be downloaded according to the students' needs. Learning videos are varied, and can be repeated if you want to add more clarity to the material. This learning video also applies the concept of 3MT (3 minute). By applying this $3 \mathrm{MT}$ concept, learning video are shorter, more compact and clearer, so students are not boring in learning. 
There are many obvious aspects of skill acquisition with which video analysis can help novice learners. In focus-group discussions the trainee teachers also talked of what could be labelled as 'intentionality'; it became clear for them from watching playback materials what levels of engagement and inter-group communication could be noted from classroom performances. These could then be used to facilitate careful interventions by the teacher in order to address issues identified from the students [22].

In the use of relevant video levels of student cognitive development, so as not to cause cognitive burden and excessive learning in the can impact understanding, as well as the assimilation of knowledge organizations. Videos can be used to reinforce knowledge because it allows students to connect images from video materials to other situations that are real in daily life. In addition, videos are considered to have intellectual contributions that can help improve students ' ability for material retention and inspire learning motivation [23]. On Zhong's research implies that interactive videos can improve student's material understanding, students look more conceptualized and able to improve problem solving physics when students are given cases [24].

The entertainment video at the beginning of the lecture motivated students towards learning, so testing results were better for that method than if a lecture without videos was used. A better effect was achieved when educational video content was used. The research from Ljubojevic [25], showed that the most efficient method of use of supplementary video is integration of educational video content in the middle of the lecture. Video-based media learning is one of the teaching aids that can alter student misconceptions and alter abstract material. With the video will display animations and images that are able to explain well. Learning with video can be combined with the blended learning model, so that the learning is active and fun. Video learning can increase learning outcome, problem solving, students skill, and motivation learning [26].

Interactive multimedia is promoted as an effective and stimulating medium for learning science, but students do not always interact with multimedia as intended by the designers [27]. Video learning based videoscribe is a multimedia interactive. With learning based videoscribe, the students easily learn from smartphone so that sometime easily interact with learning videos. The cognitive-affective theory of learning with media that we describe expands the cognitive theory of multimedia learning to media such as virtual reality, agent-based, and case-based learning environments, which may present the learner with instructional materials other than words and pictures [28-29].

Learn physics by using different books with videos. When reading, students prefer to write their own notes alongside the original text in a book or prefer marking written texts; these actions are currently impossible with video. The lessons are all in one topic area, and the contain material is too short in video. In addition, some learning strategies may be hindered by video which "streams" without clear boundaries whereas written text "stays"; that is, in video presentations, subdivisions into parts, chapters, and sub-chapters may be blurred. However, innovative modes of digital video may include subdivisions [30]. Other distinctions include how important matters are emphasized and how context is maintained. In video, emphasis is achieved by changing intonation or by adding special sound while in books it is achieved by using different type sets [31].

Learning video based videoscribe can improve students' problem solving ability in electrical measuring instruments course. Students are more understand about the problems that they face about electricity in their daily lives, and also can apply the use of electrical measuring devices. The abstract concepts that they learn become concrete, so the students are able to build the concept of electricity well. The advantage of video learning based videoscribe are the students can learn independently anytime and anywhere by opening this video that can be accessed by computer, lapotop or smartphone. Learning is more fun for studnts because the contents of learning videos are very interesting. 


\section{CONCLUSION AND SUGGESTION}

Overall, we found significant positive effects of the use of videoscribe in conveying physics lessons. These findings are consistent with studies on the improve of the student's problem-sloving ability on physics learning. They address the call to understand how affective and motivational factors can be incorporated with cognitive factors for better understanding of how people learn from video learning. While encouraging, these findings suffer from some shortcomings: the lessons are all in one topic area, and the contain is too short.

Suggestion for the researchers who will provide video learning in the form of videoscribe should be made several videos so that the material in one basic competency can be delivered, learning can also be combined with other learning models or e-learning.

\section{REFERENCES}

[1] Airey, J., \& Linder, C. (2007). Disciplinary learning in a second language: A case study from university physics. In R. Wilkinson \& V. Zegers (Eds.), Researching Content and Language Integration in Higher Education (pp. 161-171). Maastricht: Maastricht University Language Centre.

[2] Lising, L., \& Elby, A. (2005). The impact of epistemology on learning: A case study from introductory physics. American Journal of Physics, 73(4): 372-382.

[3] Anderson, J., \& Barnett, M. (2011). Using video games to support pre-service elementary teachers learning of basic physics principles. Journal of Science Education and Technology, 20(4): 347-362.

[4] Bhakti, Y. B., Astuti, I. A. D., Sumarni, R. A., Sulisworo, D., \& Toifur, M. (2019). Flipped classroom as a millennial teaching model. Indonesian Review of physics, 2(1): 22-27.

[5] Astuti, I. A. D., Sulisworo, D., \& Firdaus, T. (2019, February). What is the student response to using the weblogs for learning resources?. In Journal of Physics: Conference Series (Vol. 1157, No. 3, p. 032012). IOP Publishing.

[6] Batlolona, J. R., Baskar, C., Kurnaz, M. A., \& Leasa, M. (2018). The improvement of problemsolving skills and physics concept mastery on temperature and heat topic. Jurnal Pendidikan IPA Indonesia, 7(3): 273-279.

[7] Sulisworo, D., \& Sutadi, N. (2017). Science Learning Cycle Method to Enhance the Conceptual Understanding and the Learning Independence on Physics Learning. International Journal of Evaluation and Research in Education, 6(1): 64-70.

[8] Azizah, R., Yuliati, L., \& Latifah, E. (2015). Kesulitan pemecahan masalah fisika pada siswa SMA. Jurnal penelitian fisika dan aplikasinya (JPFA), 5(2): 44-50.

[9] Türkay, S. (2016). The effects of whiteboard animations on retention and subjective experiences when learning advanced physics topics. Computers \& Education, 98: 102-114.

[10] Moreno, R., \& Mayer, R. (2007). Interactive multimodal learning environments. Educational psychology review, 19(3): 309-326.

[11] Mayer, R. E., \& Moreno, R. (2002). Animation as an aid to multimedia learning. Educational psychology review, 14(1): 87-99.

[12] Limbong, E. (2017). Designing and Developing Supplemental Technology of PACI Model Materials through Blended Learning Methods. Celt: A Journal of Culture, English Language Teaching \& Literature, 16(2): 271-304.

[13] Derry, S. J., Pea, R. D., Barron, B., Engle, R. A., Erickson, F., Goldman, R., ... \& Sherin, B. L. (2010). Conducting video research in the learning sciences: Guidance on selection, analysis, technology, and ethics. The Journal of the Learning Sciences, 19(1): 3-53.

[14] Octavianingrum, D. (2016). Pengembangan media audio visual sparkol videoscribe dalam pembelajaran mengelola pertemuan/rapat di lembaga pendidikan profesi (lpp) ipmi kusuma bangsa Surakarta jurusan administrasi perkantoran (Doctoral dissertation, UNS (Sebelas Maret University)).

[15] Sparkol. (2019). Videoscribe for Education. Sparkol group.

[16] Rahmawati, F., Soegimin, W. W., \& Kardi, S. (2016). Pengembangan perangkat pembelajaran 
fisika model inkuiri terbimbing berbantuan videoscribe pada materi kalor untuk meningkatkan hasil belajar siswa SMAN 1 Kedungwaru. JPPS (Jurnal Penelitian Pendidikan Sains), 5(2): 1039-1047.

[17] Alias, N., \& Siraj, S. (2012). Effectiveness of Isman instructional design model in developing physics module based on learning style and appropriate technology. Procedia-Social and Behavioral Sciences, 64: 12-17.

[18] Astuti, D. P., Bhakti, Y. B., \& Astuti, I. A. D. (2019, March). Developing Adobe Flash-based mathematics learning media for 7th-grade students of junior high school. In Journal of Physics: Conference Series (Vol. 1188, No. 1, p. 012098). IOP Publishing.

[19] Erniwati, E., Eso, R., \& Rahmia, S. (2015). Penggunaan Media Praktikum Berbasis Video Dalam Pembelajaran IPA-Fisika Untuk Meningkatkan Hasil Belajar Siswa Pada Materi Pokok Suhu dan Perubahannya. Jurnal Sains dan Pendidikan Fisika, 10(3).

[20] Kirkgoz, Y. (2011). A Blended Learning Study on Implementing Video Recorded Speaking Tasks in Task-Based Classroom Instruction. Turkish Online Journal Of Educational Technology-TOJET, 10(4): 1-13.

[21] Yusup, M., Aini, Q., \& Pertiwi, K. D. (2016). Media Audio Visual Menggunakan Videoscribe Sebagai Penyajian Informasi Pembelajaran Pada Kelas Sistem Operasi. Technomedia Journal, 1(1): 126-138.

[22] Fautley, M. (2013). The potential of audio and video for formative assessment purposes in music education in the lower secondary school in England: Issues arising from a small-scale study of trainee music teachers. Journal of Music, Technology \& Education, 6(1): 29-42.

[23] Leasa, M., Syam, F. A., Sayyadi, M., \& Batlolona, J. R. (2020). Inovasi Pembelajaran Bagi Guru Sekolah Dasar Dalam Mendesain Video Pembelajaran. Publikasi Pendidikan, 10(1): 80-87.

[24] Zhang, D., Zhou, L., Briggs, R. O., \& Nunamaker Jr, J. F. (2006). Instructional video in e-learning: Assessing the impact of interactive video on learning effectiveness. Information \& management, 43(1): 15-27.

[25] Ljubojevic, M., Vaskovic, V., Stankovic, S., \& Vaskovic, J. (2014). Using supplementary video in multimedia instruction as a teaching tool to increase efficiency of learning and quality of experience. International Review of Research in Open and Distributed Learning, 15(3): 275-291.

[26] Pintado, M., \& Kathalina, C. (2017). The use of Powtoon and VideoScribe in a flipped classroom to improve listening and speaking skills on distance undergraduate students (Master's thesis).

[27] Yeo, S., Loss, R., Zadnik, M., Harrison, A., \& Treagust, D. (2004). What do students really learn from interactive multimedia? A physics case study. American Journal of Physics, 72(10): 13511358.

[28] Mayer, R. E., Dow, G. T., \& Mayer, S. (2003). Multimedia learning in an interactive self-explaining environment: What works in the design of agent-based microworlds?. Journal of educational psychology, 95(4): 806.

[29] Mayer, R. E. (2003). The promise of multimedia learning: using the same instructional design methods across different media. Learning and instruction, 13(2): 125-139.

[30] Caspi, A., Gorsky, P., \& Privman, M. (2005). Viewing comprehension: Students' learning preferences and strategies when studying from video. Instructional Science, 33(1): 31-47.

[31] Stelzer, T., Gladding, G., Mestre, J. P., \& Brookes, D. T. (2009). Comparing the efficacy of multimedia modules with traditional textbooks for learning introductory physics content. American Journal of Physics, 77(2): 184-190. 